\title{
EDITORIAL
}

\section{Happy Birthday! Professor Rudolf E. Kaiser's 90th Birthday}

Petra Russkamp ${ }^{1}$

(c) Springer-Verlag GmbH Germany, part of Springer Nature 2020

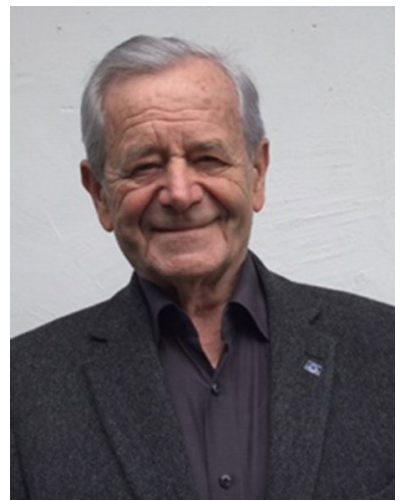

On February 12, 2020, Professor Rudolf Kaiser, the founder of Chromatographia, will celebrate his 90th birthday. In the name of the editors, publisher and readers of
Chromatographia - the chromatographic community at large, we thank Professor Kaiser for his tireless commitment to chromatography and wish him good health, success and insatiable creative energy in his professional and private endeavours.

A more detailed account of Professor Kaiser can be found in

Schomburg G. Chromatographia (2000) 51:137. https:// doi.org/10.1007/bf02490554

Frank, H. Chromatographia (2010) 71, 181-182. https:// doi.org/10.1365/s10337-010-1489-x

Angelé H-P, Struppe HG, Chromatographia (2010) 71, 183-184. https://doi.org/10.1365/s10337-010-1492-2

Petra Russkamp

Editorial Manager Chromatographia, Springer Verlag
Petra Russkamp

chromatographia@springer.com

1 Springer Verlag, Tiergartenstrasse 17, 69121 Heidelberg, Germany 